\title{
“Ngebleng" : From Corruptive Dams to Clean Water
}

\author{
Tukinu $^{1}$, Teguh Prasetyo ${ }^{2}$, Arianti R. Hunga ${ }^{3}$, Soegeng Hardiyanto ${ }^{4}$ \\ \{mr.tukinu4@gmail.com¹; prof.teguhpraseto@gmail.com²; Ina.hunga@uksw.edu*3; \\ s.hardi8844@gmail.com ${ }^{4}$ \} \\ Doctorate Degree of Development Studies of Universitas Kristen Satya Wacana, Salatiga, \\ Central Java, Indonesia ${ }^{1,2,3,4}$
}

\begin{abstract}
The Penggung dam's irrigation primary channel rehabilitation project was subjected to maintain the water supply for seven villages in Wonosegoro Sub District of Boyolali Regency, Central Java, Indonesia. The corruption case occured during the project's construction, however, had made the chanel functioned improperly. The poor quality of the infrastructure yielded, eventually, brought the communities in seven villages suffered severe drought during the dry season. The primary purpose of the study was to explain "Ngebleng" as a social strategy to attain freshwater employed by the villagers due to the compulsion of lack freshwater during the dry season. We employ ethnographical point of view to explain the strategy in the sustainable development context. The study concluded that 'ngebleng' as a social strategy employed by villagers to attain freshwater due to the dam's malfunction as a result of good governance absenteism.
\end{abstract}

Keywords: Corruption, economic and social impacts, good governance, sustainable development, Ngebleng.

\section{Introduction}

Regional autonomy which was officially implemented since the promulgation of Law No. 32 of 2004 has had an impact both positively and negatively for the region. Regional autonomy is created with the intention that regions can independently manage all resources, finance, and other sources as income for the regions. The positive impact of the implementation of regional autonomy is in terms of regional authority to regulate their own self-government [1].

Regional autonomy, on the other hand, has shifted corruption, which was previously centralized in central government, spread out to the entire regions. Fiscal management carried out in a decentralized manner, had lead into what is referred by Flejsdtad by the term of improving "marginal propensity to accept bribery" [2]. Flejsdtad, further, argues that this is caused by the fewer segments of bureaucrats can be influenced, so that the potential for corruption will be stronger. Thus, the negative impact of the existence of regional autonomy is the widespread spread of corruption down to the regions.

The spread out of corruption cases in Indonesia after regional autonomy can be seen from data released by ICW (Indonesian Corruption Watch). Based on data released by Indonesia Corruption Watch (ICW), there were 110 corruption cases involving the use of village funds involving regional leaders handled by the KPK (Corruption Eradication Commission) from January 2016 to August 2017. As a result of the corruption practices of the regional heads, state losses were estimated at 30 billion rupiahs [3]. Based on the data, there was an increase in the number of corruption losses of village funds, which in 2016 reached 10.4 billion rupiahs, it increased into 19.6 billion rupiahs in August 2017. In fact, from the data from the Ministry of Home Affairs mentioning that until June 2013, out of 524 Regional 
Heads, 297 people were involved in legal matters, both as witnesses, suspects, defendants and convicts. Of that number, $80 \%$ were involved in corruption cases.

The corruption cases committed in the regions are mostly related to the construction of infrastructure and regional budgets. One of the corruption cases in the infrastructure sector that received public attention in Central Java, especially the people of Boyolali Regency, was a corruption case that occurred during the Penggung Dam's primary irrigation channel rehabilitation project construction at Karangjati Village, Sub District of Wonosegoro.

The corruption case of the Penggung Dam irrigation channel rehabilitation project took place in the form of abuse of power done by the government officer. At the inspection schedule, the contractor requested the disbursement fund to finish the project. The corruption in Penggung Dam irrigation channel rehabilitation project, viewed from its value, was not significant. It costs about $22.54 \%$ of the project total value. The impacts, however, both in economic and social spectrum to the society are quite vast.

The corruption in the dam rehabilitation project was directly impacting the communities in seven villages along the primary irrigation channel of the dam, both economically and socially. The economic impacts of the corruption experienced by the villagers are in the forms of less productivity farming lands, the increase in farming production costs, and the increase in household expenses to provide clean water consumption. Whereas the social effects experienced by the villagers cover the decrease of the public trust on local government, the emergence of social stress and safety concerns. These impacts are experienced by around 23,577 peoples who live in seven villages along the main irrigation channel of the dam.

The improper function of the Penggung Dam irrigation channel rehabilitation project as a result of corruption became one of negative social impacts of infrastructure development. Such an impact is stated by Shleifer \& Vishny as 'shift a country's investments away from the highest value projects, such as health and education into potentially useless projects such as defence and infrastructure' [4].

Current researches proved that corruption directly impact the economic development of countries and retarded the establishment of civil society and lessen the business competitiveness. Tanwar in his research found that corruption greatly impacted Gross Domestic Product (GDP) than Human Development Index (HDI) of a country [5]. Mathew, et al., in their research also found that corruption affect economic growth in Nigeria [6]. They proposed Private Anti-Corruption Initiatives, Public anti-corruption initiatives, and education as instruments to prevent corruption in Nigeria [7].

Research undertaken by Zamahani studied the impact of corruption on social economic in Iran (Zamahani) ${ }^{[7]}$. The research concluded that the impact of corruption in Iran cover the development of poverty, the low rate of economic growth, and the occurrence of an ethical crisis and values.

Bonga et al., studied the social economy impact of corruption in Zimbabwe. They found that the impact of corruption on nation's character building includes: 1) economic growth slow-down; 2) the occurrence of talent misallocation; 3) loss of tax revenue; 4) the adverse impact on the quality of infrastructure and public services; and 5) the diversion of resource development that benefits the private sector [8]. 
Based on the background of the study explained above, the researcher eager to study the 'ngebleng' strategy practiced by the villagers in Wonosegoro to attain freshwater during the dry season. The researcher wanted to explore how the 'ngebleng' strategy practiced by the villagers as their responses toward the absence of good governance practice in the perspective of sustainable development.

The objectives of the paper are to: (1) explain 'ngebleng' as a social strategy practiced by villagers in Wonosegoro to attain freshwater during the dry season; (2) explain 'ngebleng' strategy as an impact of the corruption of Penggung dam's irrigation primary channel rehabilitation project; and (3) explain this case as a form of the absence of Good Governance practice viewed from sustainable development perspective.

\section{Methodology}

The paper is written based on a research report using case study design. Case study design, according to Yin is defined as follows "A case study need not contain a complete or accurate rendition of actual events, rather, its purpose is to establish a framework for discussion and debate among students",[9].

The paper is taken from a research about 'ngebleng' strategy as a mean practiced by the villagers to attain freshwater as an impact of the failure of Penggung dam's primary irrigation channel rehabilitation project. The research, itself, was done in Boyolali, especially in the area around the Penggung dam. The data analysis in the research is done in refer to qualitative data analysis proposed by Miles \& Huberman that consist of three main process. The process covers the following: (1) data condensation; (2) data display; and (3) verification/ conclusion drawing [10].

\section{Results and Discussion}

\section{1 "Ngebleng" as strategy of attaining freshwater due to the Penggung dam's rehabilitation project's failure}

"Ngebleng" is one of terms in Javanese language which refers to a type of tribute practice carried out based on ancient Javanese teachings. The practice of the ritual requires the perpetrator to do certain behavior for 24 hours full without being allowed to take a nap during the ritual behavior. The ritual is actually a representation of individual's willingness to get what he/she wants.

The meaning of willingnes is also can be drawn from the word "ngebleng" that used to be practiced by villagers in Wonosegoro, Boyolali, when they suffered severe draught during the dry season. The villagers submerged soil around the well for 24 hours. Such a practice is done to have the water seeped and puddled into their wells to be consumed in the following days [11].

'Ngebleng' strategy was sparked as of the villagers' compulsion in attaining freshwater in Wonosegoro area during the dry season. The villagers' compulsion of clean watter attainment was due to the failure of Penggung dam's primary irrigation rehabilitation project caused by corruption case in its implementation.

The emergence of 'ngebleng' practiced by the villagers to attain freshwater during the dry season, indicated the importance of water for human life. The villagers shoud spend a lot 
of money to attain freshwater for their families' consumption. 'Ngebleng' strategy practiced by the villagers actually is sparked as of their compulsion against the severe draught they suffered during the dry season. They expereinced difficulties to attain freshwater and suffered the severe draught during the dry season as of the failure in primary irrigation channel project rehabilitation of Penggung dam caused by the corruption case.

The corruption case in the project's implementation caused the the dam's function below the target. The dam's less optimum performance, in turn, brough about impacts on villagers in 7 villages along the primary irrigation channel of the dam. They suffered severe draught during the dry season. The economic impact suffered is mostly in the form of extra expenses to provide water consumption for domestic needs.

All houses in these villages utilize perforated well. However, all the wells are draught during the dry season. The only thing that villagers can do is to flood the land around the wells all night long so that the water perforated into the wells to be utilized in the following day. The extra expenses had to be spent to rent the generator and water pump to pull water from the nearest river.

Below is the explanation of Bolo Vilage Chief.

"We experienced difficulty to attain freshwater every dry season. Wa could not fully depend on local government's aid in fulfilling the freshwater needs. We usually share the diesel's rent to pull water from the nearest river and flood the soil around our wells all night long. We called it 'ngebleng'. Having flooded all night long, the water, then perforated into our wells to be utilized as family consumption in the following days. We flooded the soil once in a week. The expense to rent a diesel and fuel is around 500.000 rupiahs and shared together. The expense will be more expensive if the distance of the river more far. It made the water pumping can not be done using single machine. It should be done simultaneously. It means that we made post in certain distance before the water pumped to the housing area. It vsn be using 2 or 3 posts that means 2 or 3 machines"[11].

The village leader's explanation described that in every dry season, people used to suffered severe draught. All their wells could not be utilized since the muddy water. The decline of consumption water quality during the dry season suffered by the villagers along the irrigation channel of the dam endangered their health. Such a condition should be suffered since the irrigation channel function improperly as of the corruption act in its rehabilitation process.

And the only thing they coul do is flooding the soil around their wells all night long to let the water perforate into their wells or practicing 'ngebleng.' Water is pulled from the nearest river, generally around $500-1500$ meters distance, using pumping machine. The water, from the 'ngebleng' process, would perforate into the wells. The water, then, will be utilized as household. Water perforated from a single 24 hour ' $n$ gebleng' process may fulfill 7 days family consumption.

Viewed from the quantity, the money being corrupted in Penggung Dam's rehabilitation project was not so significant. It was only around Rp. 300 millions (equal to US $\$ 20.000$ ). The excess to the villagers, however, was quite vast. It affected around 11,114 farmers or equal to $42.07 \%$ of the total population of the seven villages. It also affected 674.32 
hectares of farming land that use irrigation system or equal to $65.86 \%$ of farming land all over the seven villages along the main irrigation flow of the dam [12].

It demonstrated that the corruption practice, no matter in its amount, had made massive excess on the villagers, both in the social and economic aspects. The massive impact of the corruption case in Penggung Dam's rehabilitation project is relevant to the findings of Bonga et al., that stated 'the economic and social effects of corruption are greater in developing nations than the developed world. In developed countries, where corruption is limited to a small number of projects and where common people do not encounter it on a daily basis, the adverse impact tends to be marginal and does not jeopardize the welfare of its people [8].

\section{2 'Ngebleng' as an impact of corruption of Penggung dam rehabilitation project}

The corruption committed in the rehabilitation project of Penggung Dam irrigation channel was small in its amount. The amount being corrupted was only 310,560,647.66 rupiahs (equal to US $\$ 23,385.59$ ). The impact surpassed, however, is quite enormous in term of economics. The economic impacts of the corruption of the Penggung Dam irrigation channel rehabilitiation cover the decreasing of agriculture productivity. On the other hand, the corruption had caused the increase of agriculture and live stock production costs, and household expenditure.

The improper function of the Penggung Dam irrigation channel is highly decreased the agriculture productivity, especialy in decreasing the crops product. Based on statistic data provided by the local government statistics bureau, the total harvest of rice crops from 674.32 hectares farm yard in seven villages along the irrigation channel is around 12,535 tons per year [12].

The data presented on Table 2 shows that the total harvest of rice crops around $12,535.00$ tons per year. The total harvests gained indicate that the productivity of farm yard is around 18.6 tons / hectare per year.

The cropping period, normally, is around 3 periods within a year. However, the irrigation channel improper function had made farmers crop their farm yards 2 times a year. It means that the farmers lost 1 cropping period a year or equal to $33.33 \%$ loss. On the other hand, the production cost to crop the farm yard and maintain live stocks increases during the dry season. Farmers had to spend extra expenses to rent generator and water pump to pull water from the nearest river. The expenses to rent generator and water pump in these villages is around 250.000 rupiahs per day, exclude the gas of course.

Table 2. Farming Yard in Villages along the Penggung Dam Irrigation Channel [12]

\begin{tabular}{clcc}
\hline No. & \multicolumn{1}{c}{ Village } & Farm yard (Hectares) & Crop Harvested (Tons) \\
\hline 1. & Karangjati & 230.67 & $2,200.00$ \\
2. & Banyusri & 103.52 & $1,591.00$ \\
3. & Wnsegoro & 15.00 & 929.00 \\
4. & Ketoyan & 120.28 & $2,274.00$ \\
5. & Bandung & 20.00 & $1,825.00$ \\
6. & Gosono & 100.45 & $2,227.00$ \\
7. & Bolo & 84.40 & $1,489.00$ \\
\hline
\end{tabular}


The economic impact of the corruption of the Penggung Dam irrigation channel is also suffered by households in these villages. The economic impact suffered is mostly in the form of extra expenses to provide water consumption for domestic needs. The economic impact of the improper function of the dam's irrigation channel caused by the corruption can be identified as follows:

- The decrease of agriculture productivity during dry season

- The increase of agriculture and live-stocks production cost during dry season

- The increase of domestic spending due to water resources

Based on the analysis result above, it can be concluded that corruption undermines development by distorting the rule of law and weakening the institutional foundation on which economic growth depends. The harmful effects of corruption are especially severe on the poor, who are hardest hit by economic decline, are most reliant on the provision of public services, and are least capable of paying the extra costs associated with bribery, fraud, and the misappropriation of economic privileges. The corruption, therefore, can be viewed as “...one of the greatest enemies of development [3].

\section{3 'Ngebleng' as a form of Good Governance's absence viewed from the Sustainable Development perspective}

The corruption case in the implementation had made Dam's irrigation channel rehabilitation project was unsuccessful. The building quality was too poor so that it was ruined during the maintenance period, namely 180 days after the Provisional Hand Over (PHO) signed.

The occurrence of corruption during the rehabilitation project had made the dam did not function optimally. The main objective of the rehabilitation, namely to optimize the function of the dam, was unattainable. This, in turn, brought people in seven villages along the primary irrigation channel suffered drought during dry season and lead them to practice 'Ngebleng' as a strategy to attain freshwater.

Viewed from the perspective of sustainable development, 'Ngebleng' strategy aroused from the weak practice of good governance that allow the corruption practice occured. The corruption case of Penggung Dam rehabilitation project was revealed from the Boyolali Inspectorate Report in 2012. Based on the report, the project was built improperly. The venue was reported as an undervalue project. It means that the budget allocated to build the dam being corrupted.

The discrepancy of approximately 300 millions rupiahs from the actual budget was suspected to be corrupted. The modus operandi of the corruption was done by omitting several jobs related to the project. Such an evil conspiracy was arranged together between the government's officers with the project's contractor.

The modus operandi of the corruption committed was that the actors, the government civil officers and the private company, were arranging the budget disbursement document as if the project was done completely $100 \%$, where as the project actualization was only $77.46 \%$ of the project. Therefore, the actors were subjected to infringe the Article 2 Paragraph 1 Jo Article 18 of Law (Act) No. 31/1999 on the Eradication of Corruption [13].

The corruption practice during the dam's rehabilitation project implementation was said to be antithetical to good governance. The corruption lead to the insufficient project, which in in turn made the dam work improperly. Such a condition had made the peoples in 
seven villages suffered severe draught during the dry season that sparked the idea of 'Ngebleng' as a social strategy to attain freshwater.

Based on the fact above, the corruption in the Penggung Dam's rehabilitation project had violated the concept of sustainability of development. The corruption had caused moral declination. It is relevant to Pitsoe's statement that "Corruption results in social inequality and a widening gap between the rich and the poor; civil strive; increased poverty and a lack of basic needs such as food, water and medicine; and jealousy, hatred and insecurity [14].

The above finding emphasize Matthew hypothesis that said "all corruption, no matter what its form is inimical to long term and sustainable development is indeed correct" [6]. The analysis of this investigation, examining the alleged costs of corruption on development from both normative and empirical dimensions has shown the impact on long term sustainability of development.

In different words, Mtapuri stated that "corruption may appear to have benefits to an economy and its development, but this misappropriation of finance and government resources is inimical to long term sustainable development; there is a negative relationship between corruption and the long-term rate of economic growth [15].

\section{Conclusion}

The findings of the research can be summarized as follows:

The corruption in the construction of Penggung dam's rehabilitation project lead to the low quality of the infrastructure constructed, which in turn, caused severe draught suffered by the communities in seven villages along the primary irrigation channel during the dry season. Such a catastrophe, on the other hand, had sparked a unique strategy from local wisdom called 'ngebleng.' The strategy is practiced by the villagers to attain freshwater during the dry season utilizing soil as natural filter. They flood the soil around their wells within 24 hours to let the water perforated into their wells. The water, then, utilized as household consumption water in the following day.

The corruption practice in the Penggung dam's rehabilitation project, no matter in its amount, had made massive excess on the villagers, both in the social and economic aspects. The social impact cover the decrease in public trust toward the government's apparatus, the emergence of conflict potentials among society to fight over the watering session, the unrest of facing domestic needs freshwater shortages during the dry season. Whereas, the economic aspect raised from the improper function of the dam was the increase in family's expenditure to attain freshwater both for domestic consumption and farming water.

The villagers employed 'ngebleng' strategy, adapted from local wisdom of ancient Javanese culture, to attain freshwater. The strategy of 'ngebleng' practiced by the villagers in Wonosegoro, Boyolali, can be viewed as an expression of the absence of good governance's practice in the sustainable development perspective. The corruption case in the implementation of rehabilitation project, viewed from good governance perspective is said to be antithetical to good governance practice. To be in accordance to the good governance practice, governance must reflect all the principles of good governance theory. All the principles of good governance theory should be embraced in all ramifications, ranging from justice, transparency, accountability, leadership, public participation in government, efficiency and effectiveness. 


\section{References}

[1] Widjaja, H.A.W: Otonomi Daerah dan Daerah Otonom, Jakarta: PT. Raja Grafindo Persada, 2007.

[2] Flejdstad, Odd-Helge: Decentralization and Corruption: A Review of the literature, CMI Working Papers 10, 2004.

[3] Indonesian Corruption Watch: Trend Penindakan Kasus Korupsi Tahun 2017, ICW Annual Report, 2017.

[4] Shleifer, A. \& Vishny, R.: Corruption, The Quarterly Journal of Economics, 108: 3, pp: 599-517, 2007.

[5] Tanwar, G.: Corruption and Its Impact on Development: A Cross-National Study" Quarterly Journal of Economics, vol. 110 (3), pp: 1-34, 2012.

[6] Mathew, R. E., B. Obasaju., A. I. Lawal., \& J. O. Ise: "Analysis of Corruption and Economic Growth in Nigeria." Afro Asian Journal of Social Sciences Volume 4, No. 4.2 Quarter II, pp: 1- 19, 2013.

[7] Zamahani, M.: The Political and Socio-Economic Causes and Consequences of Corruption Case Study of Iran, Journal of International Business Management, Vol. 10 No.7, pp: 1263 - 1269, 2016.

[8] Bonga, W. G., J. Chiminya, and C. Mudzingiri: An Explanatory Analysis of the Economic and Social Impact of Corruption in Zimbabwe, IOSR Journal of Economics and Finance (IOSR-JEF) Volume 6, Issue 1. Ver. I (Jan.-Feb. 2015), pp: 11-20, 2015.

[9] Yin, Robert K.: Case Study Research: Design and Methods $3^{\text {rd }}$ Edition, London: Sage Publication, 2007.

[10] Miles, Matthew B., A. Michael Huberman., \& Johny Saldana: Qualitative Data Analysis: A Methods Sourcebook $3^{\text {rd }}$ Edition, London: Sage Publications, 2014.

[11] Interview with Muhsinin, the Bolo Village Chief of Wonosegoro Sub-district, of Boyolali, 2018.

[12] Badan Pusat Statistik Boyolali: Boyolali dalam Angka. Boyolali: Pemda Boyolali, 2016.

[13] Kantor Inspektorat Boyolali: Investigasi Khusus terhadap Proyek Rehabilitasi Bendung Penggung, Investigation Report, 2012.

[14] Pitsoe, Victor J.: Values Education as a Social Instrument for Reducing Corruption, Poverty and Inequality, Mediterranean Journal of Social Sciences Vol 4 No 13 November 2013, pp: 745-753, 2003.

[15] Mtapuri, O.: Corruption and Citizen Participation: A Critical Analysis, Bangladesh e-Journal of Sociology. Volume 13, Number 1. January, 2016. 